\title{
Antifungal Activity of the Lemongrass Oil and Citral Against Candida spp.
}

\author{
Cristiane de Bona da Silva ${ }^{1,2}$, Sílvia S. Guterres ${ }^{1}$, Vanessa Weisheimer ${ }^{1}$ and Elfrides E.S.Schapoval ${ }^{1}$ \\ ${ }^{2}$ Programa de Pós-Graduação em Ciências Farmacêuticas Pos-Graduation program in Pharmaceuthical Sciences, Pharmaceutical School, \\ Federal University of Rio Grande do Sul, Porto Alegre, RS; ${ }^{2}$ CPharmaceutical School, Department of Pharmaceutical Industry, Federal \\ University of Santa Maria; Santa Maria, RS, Brazil
}

\begin{abstract}
Superficial mycoses of the skin are among the most common dermatological infections, and causative organisms include dermatophytic, yeasts, and non-dermatophytic filamentous fungi. The treatment is limited, for many reasons, and new drugs are necessary. Numerous essential oils have been tested for both in vitro and in vivo antifungal activity and some pose much potential as antifungal agents. By using disk diffusion assay, we evaluated the antifungal activity of lemongrass oil and citral against yeasts of Candida species (Candida albicans, C. glabrata, C. krusei, C. parapsilosis and C. tropicalis). This study showed that lemongrass oil and citral have a potent in vitro activity against Candida spp.
\end{abstract}

Key-Words: lemongrass oil, citral, antifungal activity, Candida spp.

Cutaneous fungal infections are common diseases in humans, and can also be caused by dermatophytic fungi and some yeasts. Superficial candidiasis is a common infection of the skin, oral cavity and esophagus, and vagina, although most infections occur in patients debilitated or who are immunocompromised. Candida albicans is responsible for many of these infections, but occasionally other members of the genus are associated, and generally infect the skin, nails, or mucous membranes [1-4]. In vulvovaginal candidiasis, C. albicans affects $85-95 \%$ of women, and $C$. glabrata affects 10-20\% [5]; C. tropicalis and C. krusei can also be associated with these infections [5,6]. Moreover, the specie C. parapsilosis is related to onychomicoses caused by Candida [6].

The conventional treatment of fungal disease is limited, and part of the reason is due to the limited spectrum of the currently antifungal drugs, and the expensive treatment, particularly due to the need of prolonged therapy. Thus, new drugs and alternative therapies are necessary, including natural products.

Essential oils of aromatic plants species are used in industries for the production of soaps, perfumes and toiletries. Many of them are also used in traditional medicine for various purposes. Investigations concerning the evaluation of the biological activities of essential oils of some medicinal plants have revealed that some of them exhibited antibacterial, antifungal and insecticidal properties [7]. Because of the antimicrobial properties showed by essential oils, the aromatherapy has been used for treatment of serious skin diseases, in special, superficial mycoses [8].

Received on 22 September 2007; revised 28 January 2008.

Address for correspondence: Dr. Cristiane de Bona da Silva. Universidade Federal de Santa Maria, Centro de Ciências da Saúde, Curso de Farmácia, Departamento de Farmácia Industrial, Av. Roraima, 1000, prédio 26, Santa Maria/RS. Zip code: 97105-900. Brazil. Phone: + 5555 32208452; Fax: + 5555 3220-9371. E-mail: csbona@smail.ufsm.br. This research was supported by CNPq.

The Brazilian Journal of Infectious Diseases

2008;12(1):63-66. (C) 2008 by The Brazilian Journal of Infectious Diseases and Contexto Publishing. All rights reserved.
Cymbopogon citratus (DC) Stapf (Gramineae) is an herb worldwide known as lemongrass. The tea made from its leaves is popularly used in Brazil as antispasmodic, analgesic, antiinflammatory, antipyretic, diuretic and sedative [9]. The volatile oil obtained from fresh leaves of this plant is widely used by the perfumes and cosmetics industries [10].

Lemongrass oil is characterized for monoterpenes compounds, and citral is the major component, present at levels of, approximately, 65-85\%. Citral (3,7-dimethyl-2,6octadienal) is the name given to a natural mixture of two isomeric acyclic monoterpene aldehydes: geranial (trans-citral, citral A) and neral (cis-citral, citral B) (Figure 1). In addition to citral, the lemongrass oil consists of small quantities of geraniol, geranylacetate and monoterpene olefins, such as myrcene [10].

Figure 1. Chemical structure of the citral.
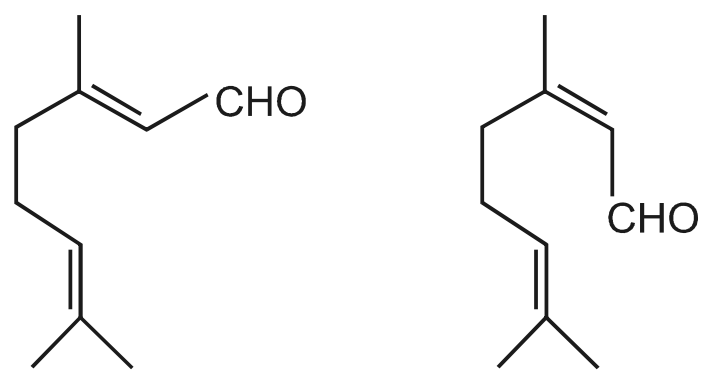

Studies on the antimicrobial, especially antibacterial and antifungal, activity of lemongrass oil and its components were reported [11-15]. The antiviral activity of this oil against Herpes simplex virus-1 was also demonstrated [16].

In this work, in order to estimate the possibility of using lemongrass oil as an antifungal agent for skin diseases (cutaneous candidiasis and dermatomycosis), the antifungal activity of this oil and its main component, citral, against Candida species was studied.

\section{Material and Methods \\ Lemongrass Oil and Citral}

The lemongrass oil (Cymbopogon citratus) was 
commercially obtained (Destilaria Maripá, Brazil) and the citral (assigned purity of 95\%) was supplied by Sigma-Aldrich (Darmstadt, Germany). The percentage of citral (neral and geranial) in the lemongrass oil was $76 \%$, assayed by gas chromatography.

\section{Antifungal Assay}

The antifungal activity of the lemongrass oil and citral against yeasts was determined using the disk diffusion method [13]. Eight strains of Candida species were used: Candida albicans ATCC 10231, Candida albicans ATCC 18804, Candida albicans CI-I (clinical isolate), Candida albicans CI-II, Candida krusei ATCC 6258, Candida glabrata ATCC 2001, Candida tropicalis ATCC 750 and Candida parapsilosis ATCC 22019. The cultures of Candida spp. were cultivated on Sabouraud dextrose $4 \%$ agar (SDA) at $25^{\circ} \mathrm{C}$ for 48 hours. Suspensions of yeasts were prepared in saline solution of $25 \% \pm 2 \%$ turbidity, obtained at $580 \mathrm{~nm}$, using a suitable spectrophotometer (Analyser Model 800, São Paulo, Brazil). Seeded agar plates were prepared by pouring $20 \mathrm{~mL}$ of SDA into each sterile plate. After solidification of medium, each plate was overlaid with $5 \mathrm{~mL}$ of SDA, which was previously inoculated with $1 \%(\mathrm{v} / \mathrm{v})$ of the suspensions of yeasts. Lemongrass oil and citral were applied on filter paper disks $(2.0,4.0$ and $8.0 \mu \mathrm{L} / \mathrm{disk})$ of $6 \mathrm{~mm}$ in diameter. Nystatin solution
$(0.3 \mathrm{mg} / \mathrm{mL})$ was used as antifungal reference substance $(20.0$ $\mu \mathrm{L} /$ disk). These disks were placed on the surface of seeded agar plates (one disk for plate). All plates were incubated at $35^{\circ} \mathrm{C} \pm 2^{\circ} \mathrm{C}$ for 24 hours. The inhibition zone was determined by measuring the diameter of the clear zone around each disk with a paquimeter (Starret $\circledast$, Itu, Brazil). Six disks were used for each sample.

\section{Results}

In this work, the antifungal activity against other Candida species was also studied, and the results obtained showed the important antifungal activity of lemongrass oil and citral. Candida albicans is an important pathogen of human infections; moreover, other species can be associated with some infections.

Different yeasts were tested and the antifungal activity of lemongrass oil and its major component (citral) was evaluated against Candida spp. Results from the antifungal activity are summarized in Tables 1 and 2. They show that the lemongrass oil and the citral exhibited action against all Candida spp., especially $C$. albicans species, with a partial inhibition when a volume of $8.0 \mu \mathrm{L}$ of each sample was employed (diameter inhibition zone higher than $40 \mathrm{~mm}$ ). On the other hand, $C$. krusei was the more resistant specie, showing a diameter inhibition zone minor than $20 \mathrm{~mm}$ using $8.0 \mu \mathrm{L}$ of each sample. In the present work, the citral concentration in lemongrass oil

Table 1. Diameter of inhibition zone of the lemongrass oil against some Candida species $(\mathrm{n}=6)$

\begin{tabular}{|c|c|c|c|c|}
\hline \multirow{2}{*}{ Test strain } & \multicolumn{3}{|c|}{$\begin{array}{c}\text { Diameter of inhibition zone }(\mathrm{mm}) \\
\text { Lemongrass oil }(\mu \mathrm{L})\end{array}$} & \multirow{2}{*}{$\begin{array}{c}\text { Nystatin solution } \\
(0.3 \mathrm{mg} / \mathrm{mL}, 20.0 \mu \mathrm{L})\end{array}$} \\
\hline & 2.0 & 4.0 & 8.0 & \\
\hline C. albicans ATCC 10231 & 18.6 & 27.4 & $>40$ & 18.8 \\
\hline C. albicans ATCC 18804 & 13.3 & 22.5 & $>35$ & 18.8 \\
\hline C. albicans CI-I & 12.6 & 27.3 & $>40$ & 17.8 \\
\hline C. albicans CI-II & 14.4 & 27.3 & $>50$ & 17.9 \\
\hline C. glabrata ATCC 2001 & 19.3 & 25.1 & $>30$ & 17.3 \\
\hline C. krusei ATCC 6258 & 12.3 & 14.4 & 19.6 & 15.4 \\
\hline C. parapsilosis ATCC 22019 & 8.9 & 18.3 & 28.6 & 13.5 \\
\hline C. tropicalis ATCC 750 & 12.8 & 19.2 & 29.5 & 15.6 \\
\hline
\end{tabular}

Table 2. Diameter of inhibition zone of the citral against some Candida species $(n=6)$

\begin{tabular}{|c|c|c|c|c|}
\hline \multirow{2}{*}{ Test strain } & \multicolumn{3}{|c|}{$\begin{array}{c}\text { Diameter of inhibition zone }(\mathrm{mm}) \\
\text { Reference citral }(\mu \mathrm{L})\end{array}$} & \multirow{2}{*}{$\begin{array}{c}\text { Nystatin solution } \\
(0.3 \mathrm{mg} / \mathrm{mL}, 20.0 \mu \mathrm{L})\end{array}$} \\
\hline & 2.0 & 4.0 & 8.0 & \\
\hline C. albicans ATCC 10231 & 14.6 & 27.8 & $>40$ & 18.6 \\
\hline C. albicans ATCC 18804 & 12.5 & 20.6 & $>35$ & 18.8 \\
\hline C. albicans CI-I & 14.8 & 20.3 & $>40$ & 17.8 \\
\hline C. albicans CI-II & 14.5 & 26.1 & $>35$ & 18.5 \\
\hline C. glabrata ATCC 2001 & 18.8 & 22.5 & $>30$ & 17.3 \\
\hline C. krusei ATCC 6258 & 12.3 & 14.3 & 19.7 & 15.1 \\
\hline C. parapsilosis ATCC 22019 & 9.0 & 18.1 & 27.5 & 14.0 \\
\hline C. tropicalis ATCC 750 & 12.4 & 22.2 & 32.6 & 18.1 \\
\hline
\end{tabular}


was $76 \%$, and the citral quantity expected in 2,4 and $8 \mu \mathrm{L}$ of this oil was, approximately, $1.35,2.70$ and $5.41 \mathrm{mg}$, respectively.

\section{Discussion}

Numerous essential oils have been tested for in vivo and in vitro antimycotic activity and some demonstrated to be potential antifungal agents. Their mechanism of action appears to be predominantly on the fungal cell membrane, disrupting its structure causing leakage and cell death; blocking the membrane synthesis; inhibition of the spore germination, fungal proliferation and cellular respiration [8]. Because of high volatility and lipophilicity of the essential oils, they are readily attached to penetrate into the cell membrane to exert their biological effect [17].

The antifungal activity of lemongrass oil has been tested against some species that induced human infections, including dermatophyte species and C. albicans $[11,12,18,19]$. Onawunmi (1989) reported that the MIC value obtained for citral against C. albicans was $0.05 \%(\mathrm{v} / \mathrm{v})$, and this value was similar to those obtained in studies with lemongrass oil [11]. In addition, the lemongrass oil $(100 \mu \mathrm{g} / \mathrm{mL})$ and citral $(25-200 \mu \mathrm{g} / \mathrm{mL})$ inhibited the mycelial growth of $C$. albicans, suggesting the potential value of lemongrass oil for the treatment of cutaneous candidiasis [19]. Additionally, pre-clinical studies were conducted with ointments containing essential oils, including lemongrass oil. The animals were infected with dermatophyte fungi (T. rubrum and M. gypseum), and the results showed the efficacy of this preparation [20].

The susceptibility of Candida spp. to antifungal agents is not uniform, and several resistance mechanisms have been related (changes in the cell wall or plasma membrane, mutations, sequestration of the antifungal in organelle-like vacuoles, or chromosomal changes). Candida krusei is resistant to some triazoles [3], and these observations can explain the minor efficacy showed by lemongrass oil and citral. Nystatin is used as a reference substance, and in comparison with that drug, the samples of the oil and citral showed higher activity. In addition, using volumes of 4.0 and $8.0 \mu \mathrm{L}$ of the lemongrass oil and the reference citral it was observed asymmetric diameter inhibition zones and lower growing around these inhibition zones. These observations can be explained by the evaporation of the essential oil and by different vapor concentration into the agar layer. In a previous work carried out in our laboratory, a total inhibition of the growing yeast was observed using $20.0 \mu \mathrm{L}$ of the lemongrass oil [13].

The antifungal activity presented by lemongrass oil and citral were similar, and corroborates with literature, which indicated significant association between the effect and the presence of citral in lemongrass oil $[11,12,21]$. Literature points that citral acts as a fungicidal agent because it is able to form a charge transfer complex with an electron donor of fungal cells, resulting in fungal death [22].

These results demonstrated the potentiality of using the lemongrass oil instead of the citral in pharmaceuticals preparations, because of its similar antifungal activity, the minor cost and toxicity. Citral is a widely used fragrance and flavor material with a strong lemon-like odor. It is reported to be sensitizer and irritant [23,24]. Opdyke (1976) reported that three aldehydes (cinnamic aldehyde, phenylacetaldehyde and citral) were shown to be sensitizers in a human maximization test; however, essential oils that contain significant amounts of each material did not induce sensitization [25].

It was observed very good effectiveness and broadspectrum activity against Candida species. In our researches, topic formulations containing this oil were developed and evaluated [26], and subsequent clinical studies are necessary. Besides, in vivo and in vitro studies have been conducted to assess skin irritation.

\section{Acknowledgements}

The authors are grateful to Professor Maria L. Scroferneker of the Instituto de Ciências Básicas da Saúde/UFRGS for providing the species. This research was supported by CNPq.

\section{References}

1. Hall J.C. Sauer's manual of skin diseases. 8. ed. Philadelphia: Lippincot Williams \& Wilkins, 1999.

2. Lacaz C.S., Porto E., Martins J.E.C., et al. Tratado de micologia médica, São Paulo, Sarvier, 2002.

3. Eggimann P., Garbino J., Pittet D. Epidemiology of Candida species infections in critically ill non-immunosuppressed patients. Lancet Infect Dis 2003;3:685-702.

4. Hay R. Superficial fungal infections. Skin and Soft Tissue Infections 2005;33:89-90.

5. Sobel J.D. Vulvovaginal candidosis. Lancet 2007;369:1961-71.

6. Develoux M., Bretagne S. Candidosis et levuroses diverses. EMCMaladies Infectieuses 2005;2:119-39.

7. Burt S. Essential oils: their antibacterial properties and potential applications in foods-a review. Int $\mathrm{J}$ Food Microbiol 2004;94:223-53.

8. Harris R. Progress with superficial mycoses using essential oils. International Journal of Aromatherapy 2002;12:83-91.

9. Carlini E.A., Contar J.D.P., Silva-Filho A.R., et al. Pharmacology of lemongrass (Cymbopogon citratus Stapf). I. Effects of teas prepared from the leaves on laboratory animals. J Ethnopharmacol 1986; 17:37-64.

10. Ferreira M.S.C., Fonteles M.C. Aspectos etnobotânicos e farmacológicos do Cymbopogon citratus Stapf (capim limão). Revista Brasileira de Farmácia 1989;70:94-7.

11. Onawunmi G.O. Evaluation of the antimicrobial activity of citral. Lett Appl Microbiol 1989;9:105-8.

12. Wannissorn B., Jarikasem S., Soontorntanasart T. Antifungal activity of lemon grass and lemon grass oil cream. Phytotherapy Res 1996; 10:551-4.

13. Schuck V.J.A., Fratini M., Rauber C.S., et al. Avaliação da atividade antimicrobiana de Cymbopogon citratus. Revista Brasileira de Ciências Farmacêuticas 2001;37:45-9.

14. Paranagama P.A., Abeysekera K.H.T., Abeywickrama K., Nugaliyadde L. Fungicidal and anti-aflatoxigenic effects of the essential oil of Cymbopogon citratus (DC.) Stapf (lemongrass) against Aspergillus flavus Link. Isolated from stores rice. Lett Appl Microbiol 2003;37:86-90.

15. Wannissorn B., Jarikasem S., Siriwangechain, T., Thubthimthed, S. Antibacterial properties of essential oils from Thain medicinal plants. Fitoterapia 2005;76:233-6.

16. Minami M., Kita M., Nakaya T., et al. The inhibitory effect of essential oils on Herpes simples virus type-1 replication in vitro. Microbiol Immunol 2003;47:681-4. 
17. Inouye S. Laboratory evaluation of gaseous essential oils (part 1). International Journal of Aromatherapy 2003;13:95-107.

18. Inouye S., Uchida K., Yamaguchi In vitro and in vivo antiTrichophyton activity of essential oils by vapour contact. Mycoses 2001;44:99-107.

19. Abe S., Sato Y., Inouye S., et al. Anti-Candida albicans activity of essential oils including lemongrass (Cymbopogon citratus) oil and its component, citral. Jpn J Med Mycol 2003;44:285-91.

20. Kishore N., Mishra A.K., Chansouria P.N. Fungitoxicity of essential oils against dermatophytes. Mycoses 1993;36:211-5.

21. Onawunmi G.O., Yisak W-A.B., Ogunlana E.O. Antibacterial constituents in the essential oil of Cymbopogon citratus (DC.) Stapff. J Ethnopharmacol 1984;12:279-86.

22. Kurita N, Miyaji M., Kurane R., Takahara Y. Antifungal activity of components of essential oils. Agric Biol Chem 1981;45:945-52.
23. Allenby C.F., Basketter D.A., Dickens A., et al. An arm immersion model of compromised skin (I). Influence on irritation reactions. Contact Dermatitis 1993;28:84-8.

24. Heydorn S., Menné T., Andersen K.E., et al. Citral a fragrance allergen and irritant. Contact Dermatitis 2003; $49: 32-6$.

25. Opdyke D.L.J. Inhibition of sensitization reactions induced by certain aldehydes. Food Cosmet Toxicol 1976; $14: 197-8$.

26. UFRGS, Escritório de Interação e Transferência de Tecnologia. Rauber C.S., Guterres S.S., Henriques A.T., Schapoval E.E.S. Composições farmacêuticas para o tratamento de afecções cutâneas causadas por Candida sp. e fungos dermatófitos e uso de óleo volátil de $C$. citratus nas ditas composições. BR200203521-A, 2002. 